\title{
SmartPhones improving clinical outcomes
}

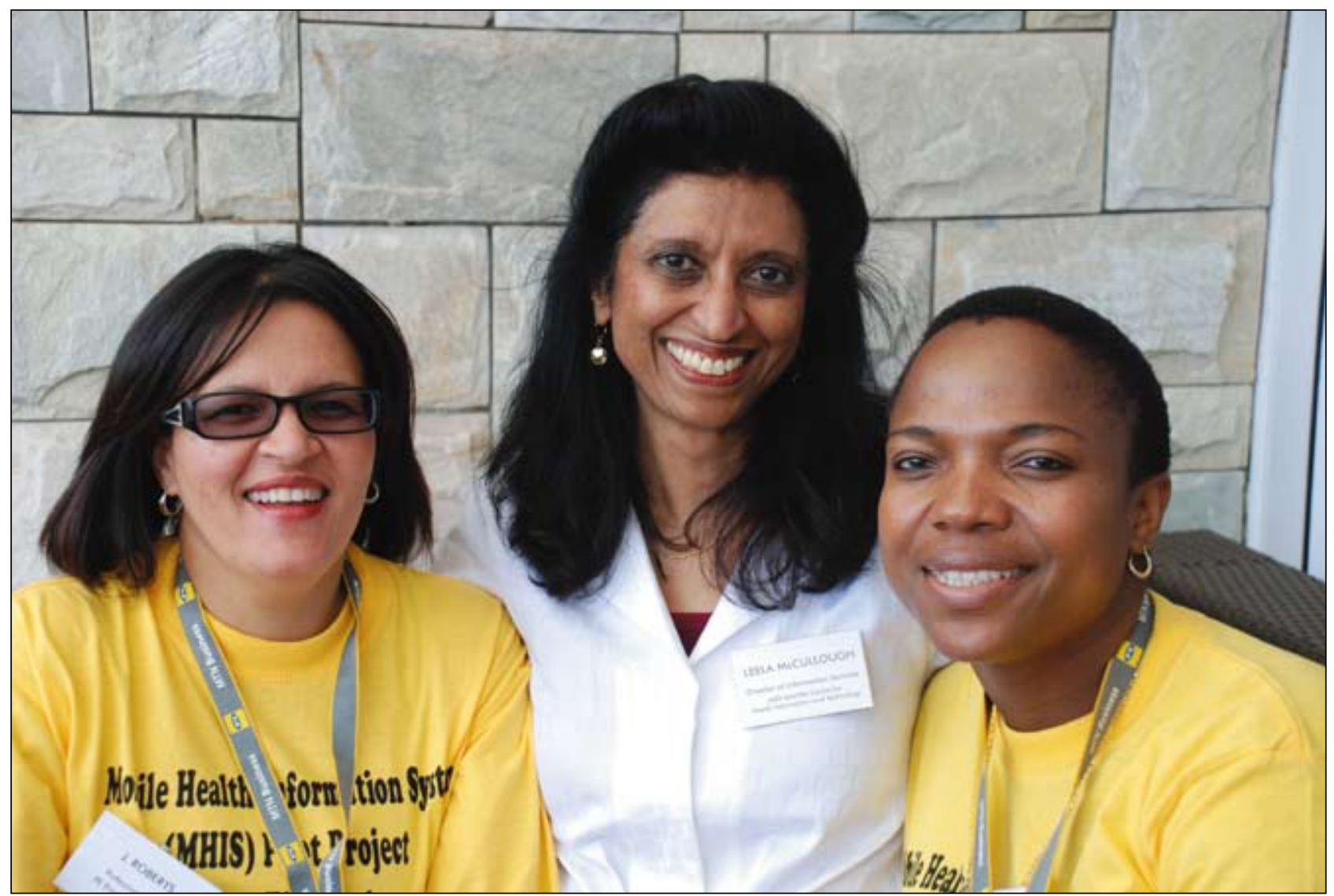

Leela McCollough, Director of Information Services at the United States-based Academy for Educational Development (AED), is flanked by her trainees, Port Elizabeth nurses, Jessmina Roberts (left) and Lulama Gqamana.

Picture: Chris Bateman

\begin{abstract}
A group of 50 Port Elizabeth nurses are fighting off their colleagues and the doctors they work with to hold onto SmartPhones that provide them with instant and almost limitless access to a clinical library and treatment guidelines.
\end{abstract}

They are the guinea pigs in a 22-monthold mobile health information pilot project, a joint initiative of the Eastern Cape Health Department, MTN, Nelson Mandela University and global telecommunications company, Qualcomm Wireless Reach. It is expected to boost patient care in the city's three major hospitals, and perhaps eventually province-wide and even nationally.

The Eastern Cape's Health DirectorGeneral, Dr Siva Pillay, was enthusiastic about the expansion potential of what he says will one day be as common a clinical tool as the stethoscope, citing uses such as teaching, accessing patient histories and clinical records (encrypted for confidentiality) and vital drug data (dosages, indications, availability, etc.).
Emphasising the power of public/private partnerships, Pillay said that during times of resource constraints, embracing technology was paramount if his provincial department was to become cost-effective. (His budget deficit was last year reduced from R2.4 billion to R1.6 billion through a series of rationalisation and fraud-busting efforts.) Pillay warned the 50 nurses present at the Port Elizabeth beachfront hotel launch of the device not to 'confuse information with knowledge', while commending them for embracing a technology that had at first intimidated them.

Leela McCollough, Director of Information Services at the United States-based Academy for Educational Development (AED), reminded her 50 trainees, carefully chosen from a variety of hospital departments, how they were tempted to 'pull their hair out' when training started in January 2009. She said many of them had been forced to learn how to type and played simple games on the device simply to become familiar with it, even though most of them had used cell phones before.

McCollough said AED had three aims: to demonstrate to the nurses that they could use mobile devices in a clinical care setting, that they could access the information on it and, most importantly, that they could apply that information in practice.

Each device has a library of some 30 documents and over 1000 pages of text, ranging from local treatment guidelines (HIV/AIDS, primary care) to local disease directories, autism, cancer, cholera, diarrhoea, epilepsy and malaria. Users can also surf the Net, download e-mails and/or attachments onto their memory card, send e-mails and make calls.

Ongoing training and technical support is being provided at all three hospitals, with nurses themselves doing peer group training while AED up-skills the relevant IT staff and MTN stays on permanent standby in case their help is needed. 
Tool evaluation: $\mathbf{9 0 \%}$ say it's a performance booster

Dr Essie Ricks, a senior lecturer in the Nursing Science Department at Nelson Mandela University, evaluated the project and said $80 \%$ of the group, most of whom had no prior computer skills, experienced the device (after training) as good to very good', with over $90 \%$ finding the Eastern Cape disease directory on it the most helpful and $86.5 \%$ voting for the standard treatment guidelines as their favourite folder. Over $70 \%$ of the group found the device 'very easy' to use while nearly $90 \%$ said it helped them update their knowledge of the management and treatment of various conditions.

Ricks said the device aroused intense interest among other nurses and doctors, who pleaded for there to be 'one per ward' and vowed to buy one if they could source one.

\section{The SmartPhone meant nurses could access information and share it with colleagues and patients, especially those working in remote clinics, who needed such back-up to function optimally. Rare and complex cases could be more quickly and successfully treated and fast- moving epidemics kept up with.}

The SmartPhone meant nurses could access information and share it with colleagues and patients, especially those working in remote clinics, who needed such back-up to function optimally. Rare and complex cases could be more quickly and successfully treated and fast-moving epidemics kept up with.

Jessmina Roberts, a registered nurse with 20 years' experience at the PE Provincial Hospital, said there was no longer any need for her to 'read up' when she got home in the evening. 'It's like a small notebook right at hand. You've easy access and you can share it or download it onto your PC. At home everybody looks up to you. My children wish they could have it instead of going to college!' Roberts said that because she 'can't remember everything' she sometimes used the medical calculator to work out fluid dosages for dehydrated patients in casualty. 'The doctors find this fascinating. I work in cardiology and the doctors ... I have to fight to get it back from them sometimes. I've also helped a lot of students with their research, she revealed.

Another nurse, Lulama Gqamana of the paediatric AIDS department at Dora
Nginza Hospital, said the device was excellent for keeping up with fast-changing ART guidelines. 'When President Zuma announced that the new (HIV) guidelines would be rolled out in April, we had it on here even before his announcement. Also the microbicide gel trial results (from KwaZuluNatal); we knew about them before they were on the news. We get updated e-mails twice a week which we share with the doctors, making them very happy', she laughed.

\section{'The doctors find this fascinating. \\ I work in cardiology and the} doctors ... I have to fight to get it back from them sometimes. I've also helped a lot of students with their research,' she revealed.

One of the biggest advantages of the device's popularity for her was 'exposure to other units, which makes you more generalist'. 'Yes we gave our teachers grey hair but we can show them now. I wasn't even computer literate and today I can say I'm a champion,' she grinned.

The value of the device comes into sharp focus when you consider how few public health workers have access to vital health information tools, reflecting the broader picture where $10.8 \%$ of South Africans have Internet access and only $0.09 \%$ broadband Internet access.

\section{Bureaucracy bedevilling capacity}

Pillay said that he would continue to plague his provincial financial department to fund a Virtual Private Network (VPN) for his 700 clinics and 100 hospitals because of the huge information-sharing and teaching benefits. 'I can prove to them that R 800 million is not too much when you do a proper cost-benefit analysis. How much money do you waste with duplicate payments and corruption? We have the ingredients - we just have to bake the cake!' Pillay is a former parliamentarian who also worked in the Department of Public Enterprises. He fought 'tooth and nail' with the Independent Communications Authority of South Africa (ICASA) - the regulator for the South African communications, broadcasting and postal services sector, because of their tardy licensing of the state to enable optimal use of the country's new fibre-optic capability. This capability came with the connection of the West Atlantic Cable between London and Cape Town in December 2009, but remained restricted to the private sector which snapped up the VPN capability to expand capacity and efficiency. 'The Eastern Cape is fully covered on fibre-optic - we just need the private sector to cover the "last mile" and we'd be up and running (on VPN), Pillay revealed.

MTN's Motseki Majake, senior manager for government-MTN business, said that to expand the SmartPhone's reach a GPS network could be used to establish exactly where there was no signal and boosters constructed to extend coverage for deep rural areas. 'We worked with Transnet when they wanted to put in cell phone coverage on the rail network and they adopted this kind of discussion to monitor trains countrywide,' he said.

Pillay said it was 'all about packaging' the components brought to the table by various role players, adding: 'How do you make it affordable and then package? You have to think outside the box.'

Elizabeth Migwalla, Senior Director of Government Affairs for Qualcomm, told Izindaba that the next step for the SmartPhone project would be to identify 'which other nurses, where, why and how' 'Will nurses and doctors like it enough to pay R100 per month to have it or will the health department subsidise it at R50 per nurse? Whatever model we consider it must be sustainable, collaborative and financially viable, she added.

\section{'Will nurses and doctors like it enough to pay R100 per month to have it or will the health department subsidise it at $\mathbf{R 5 0}$ per nurse? Whatever model we consider it must be sustainable, collaborative and financially viable,' she added.}

Qualcomm and other stakeholders in the project are probing the Universal Service and Access Agency of South Africa (USAASA) to try and access its huge reserves established to roll out technology to rural areas. USAASA was established in 2005 under the Electronic Communications Act to promote universal access in under-serviced areas of South Africa and is funded via a special tax on telecommunication operators. It has built up huge reserves, now the subject of heated debate around their use.

Migwalla said if successful, USAASA funds would be used to source the SmartPhone at a reduced price and to subsidise connectivity rates.

\section{Chris Bateman}

